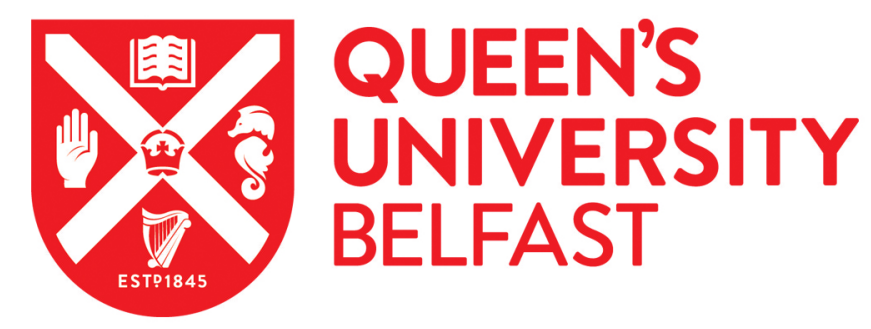

\title{
The First Continuous Flow Hydrogenation of Amides to Amines
}

\author{
Manyar, H. G., Hardacre, C., Cole-Hamilton, D. J., \& Coetzee, J. (2013). The First Continuous Flow \\ Hydrogenation of Amides to Amines. CHEMCATCHEM, 5(10), 2843-2847. \\ https://doi.org/10.1002/cctc.201300431
}

\section{Published in: \\ CHEMCATCHEM}

\section{Document Version:}

Early version, also known as pre-print

\section{Queen's University Belfast - Research Portal:}

Link to publication record in Queen's University Belfast Research Portal

\section{Publisher rights}

Copyright 2013 The authors.

This is the pre-peer reviewed version of the following article: Coetzee, J., Manyar, H. G., Hardacre, C. and Cole-Hamilton, D. J. (2013), The First Continuous Flow Hydrogenation of Amides to Amines. ChemCatChem, 5: 2843-2847., which has been published in final form at doi: $10.1002 /$ cctc. 201300431

\section{General rights}

Copyright for the publications made accessible via the Queen's University Belfast Research Portal is retained by the author(s) and / or other copyright owners and it is a condition of accessing these publications that users recognise and abide by the legal requirements associated with these rights.

Take down policy

The Research Portal is Queen's institutional repository that provides access to Queen's research output. Every effort has been made to ensure that content in the Research Portal does not infringe any person's rights, or applicable UK laws. If you discover content in the Research Portal that you believe breaches copyright or violates any law, please contact openaccess@qub.ac.uk. 


\title{
The First Continuous Flow Hydrogenation of Amides to Amines
}

\author{
Jacorien Coetzee, ${ }^{[a]}$ Haresh G. Manyar,${ }^{[b]}$ Christopher Hardacre ${ }^{[b]}$ and David J. Cole-Hamilton ${ }^{*[a]}$
}

Amines are a versatile class of compounds with applications ranging from dyes, solvents and detergents to the pharmaceutical industry. Amine functionalities are often introduced by initial amide formation followed by a reduction step using reducing agents such as $\mathrm{LiAlH}_{4}$ or boranes. These reducing agents are, however, hazardous and difficult to handle, particularly on large scale, and often involve complex and wasteful work-up procedures. Thus, routes to selective and environmentally benign amide reduction are sought after and for this reason the American Chemical Society Green Chemistry Institute (GCl) and members of the Pharmaceutical Round Table have shortlisted amide hydrogenation as one of their three most desirable reactions for development. ${ }^{[1]}$ Although a number of successful amide reductions via catalytic hydrosilylation have been reported, ${ }^{[2]}$ catalytic hydrogenation represents a promising alternative since water is generated as the only by-product. The groups of Saito, ${ }^{[3]}$ Milstein $^{[4]}$ and Bergens ${ }^{[5]}$ reported homogeneously catalysed hydrogenation of amides, but in all cases the reduction either proceeds via $\mathrm{C}-\mathrm{N}$ bond cleavage to give amines and alcohols or via monohydrogenation to give hemiaminals. We recently, reported the first successful homogeneous Ru-based catalyst capable of selectively hydrogenating amides to amines without $\mathrm{C}-\mathrm{N}$ bond cleavage even in the presence of aromatic ring systems. ${ }^{[6]}$ The scope of this reaction is, however, currently limited to substrates containing a phenyl ring directly attached to $\mathrm{N}$ or primary amides. A number of bimetallic heterogeneous hydrogenation catalysts has been reported by the groups of Fuchikami ${ }^{[7]}$ and Whyman ${ }^{[8]}$ to give good conversions of amides to amines, but they generally require fairly harsh operating conditions. More recently, promising bimetallic graphite supported $\mathrm{Pd}-\mathrm{Re}$ and $\mathrm{TiO}_{2}$ supported Pt-Re based catalysts capable of promoting amide hydrogenations under mild reaction conditions have been reported independently by the groups of Breit ${ }^{[9]}$ and Hardacre. ${ }^{[10]}$ Although the use of heterogeneous catalyst for amide hydrogenations is currently limited to non-aromatic substrates

[a] Dr. J Coetzee, Prof. D. J. Cole-Hamilton

EastChem, School of Chemistry, North Haugh

University of St. Andrews

St. Andrews, Fife

KY16 9ST, Scotland (United Kingdom)

Fax: (+)44 (0)1334 463808; Tel: (+)44 (0)1334 463805

E-mail:djc@st-andrews.ac.uk

[b] Dr. H. G. Manyar, Prof. C. Hardacre

CenTACat, School of Chemistry and Chemical Engineering

Queen's University

Stranmillis Road, Belfast

BT9 5AG, Northern Ireland (United Kingdom)

Supporting information for this article is available on the WWW under http://dx.doi.org/10.1002/cctc.200xxxxxx. owing to the complication of unwanted ring hydrogenation, the ease of catalyst separation associated with such systems is of great advantage to their implementation in continuous flow systems for industrial application. Herein, we report the first selective catalytic hydrogenation of amides to amines in continuous flow using the bimetallic $\mathrm{TiO}_{2}$ supported $\mathrm{Pt}-\mathrm{Re}$ based catalyst. $^{[10]}$

The air stable $4 \% \mathrm{Pt}-4 \% \mathrm{Re} / \mathrm{TiO}_{2}$ catalyst employed in this study was first reported to be catalytically active towards amide hydrogenation by some of us. ${ }^{[10]} \mathrm{A}$ range of bimetallic $\mathrm{Pt}-\mathrm{Re}$ based catalysts supported on $\mathrm{CeZrO}_{4}, \mathrm{TiO}_{2}$ and $\mathrm{Al}_{2} \mathrm{O}_{3}$ were tested for the selective hydrogenation of $\mathrm{N}$-methylpyrrolidin-2one to $\mathrm{N}$-methylpyrrolidine in hexane under 20 bar of hydrogen at $120{ }^{\circ} \mathrm{C}$. Under these conditions, $4 \% \mathrm{Pt}-4 \% \mathrm{Re} / \mathrm{TiO}{ }_{2}$ displayed the highest activity, giving almost full conversion after $24 \mathrm{~h}$. For this system, the nature of the solvent was shown to play an important role, with the rate of the reaction decreasing in the order: hexane $>$ tetrahydrofuran $\sim$ diethyl ether $>$ methanol $>$ methyl tert-butyl ether. ${ }^{[10]}$

To assess the performance of this catalyst under continuous flow conditions, we have developed a versatile flow reactor. The reactor is vertical with an upwards flow and has the facility to flow liquids, gases and $\mathrm{CO}_{2}$ simultaneously through the vertical packed bed reactor containing the catalyst. The flowing stream is then decompressed and the products are collected free from catalyst and other impurities apart from side products, solvent and unreacted substrates. A schematic of the reactor is shown in Figure 1.

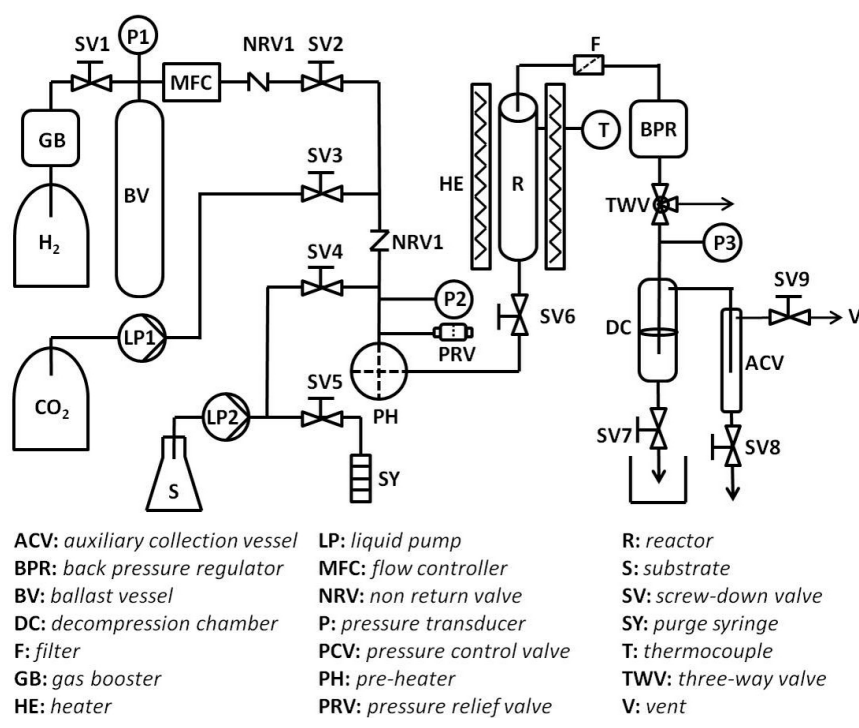

Figure 1. Schematic drawing of the continuous flow reactor. 
Prior to testing the $4 \% \mathrm{Pt}-4 \% \mathrm{Re} / \mathrm{TiO}_{2}$ in continuous flow, the catalyst was tested in batch mode with an aromatic substrate to determine the tolerance of this catalyst towards arene functionalities. Acetanilide, a substrate which performed very well with the homogeneous $\left[\mathrm{Ru}(\mathrm{acac})_{3}\right] /$ triphos [where triphos $=$ 1,1,1-tris(diphenylphosphinomethyl)ethane] system (Entry 1, Table 1), was used as test substrate. ${ }^{[6]}$ Acetanilide $(5 \mathrm{mmol})$ in hexane was heated at $160{ }^{\circ} \mathrm{C}$ in the presence of $4 \% \mathrm{Pt}-$ $4 \% \mathrm{Re} / \mathrm{TiO}_{2}$ (1.6 mol \% in metal) under hydrogen (20 bar at room temperature) for $16 \mathrm{~h}$. Although this did result in hydrogenation of $36 \%$ of the amide functionality, ring hydrogenation occurred for both the final amine as well as the remaining substrate to give a mixture of $\mathrm{N}$-cyclohexyl- $\mathrm{N}$-ethylamine (2) and $\mathrm{N}$ cyclohexylacetamide (3) as the final products (Scheme 1). In addition, minor amounts of cyclohexanamine (4) and ethanol (5) were produced as a result of $\mathrm{C}-\mathrm{N}$ bond cleavage.

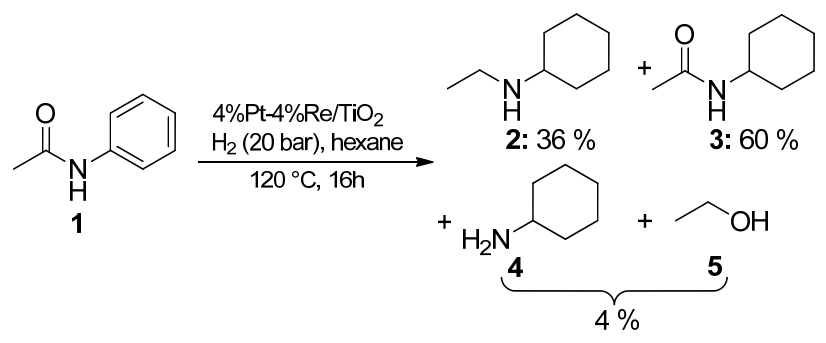

Scheme 1. Catalytic hydrogenation of acetanilide in batch mode using $4 \% \mathrm{Pt}-$ $4 \% \mathrm{Re} / \mathrm{TiO}_{2}$.

Table 1. A comparison between the homogeneous and heterogeneous catalytic systems in the hydrogenation of amides to amines in batch mode.

$\begin{array}{llclll}\text { Entry Substrate } \quad \text { Catalyst } & \begin{array}{c}\text { Time } \\ \text { (h) }\end{array} & \text { Product } & \begin{array}{c}\text { Conv } \\ (\%)\end{array} & \begin{array}{c}\text { Sel. } \\ (\%)\end{array}\end{array}$

Homogeneous system ${ }^{[a]}$

$\left[\mathrm{Ru}(\mathrm{acac})_{3}\right] /$
triphos

Heterogeneous system ${ }^{[c]}$

\begin{tabular}{|c|c|c|c|c|}
\hline 4 & $\begin{array}{c}4 \% \mathrm{Pt}-4 \% \mathrm{Re} / \\
\mathrm{TiO}_{2}\end{array}$ & 16 & 100 & 0 \\
\hline 5 & $\begin{array}{c}4 \% \mathrm{Pt}-4 \% \mathrm{Re} / \\
\mathrm{TiO}_{2}\end{array}$ & 16 & 100 & 100 \\
\hline 6 & $\begin{array}{c}4 \% \mathrm{Pt}-4 \% \mathrm{Re} / \\
\mathrm{TiO}_{2}\end{array}$ & 16 & 97 & 74 \\
\hline
\end{tabular}

Conditions: [a] Amide (5 mmol), [Ru(acac) $)_{3}$ ( $\left.1 \mathrm{~mol} \%\right)$, triphos $(2 \mathrm{~mol} \%)$, thf $(10 \mathrm{ml})$, MSA (1.5 mol \%), $\mathrm{H}_{2}(15 \mathrm{bar}), 220^{\circ} \mathrm{C}$, Hastelloy ${ }^{\mathrm{TM}}$ autoclave. [b] The main side-products were methyldipropylamine $(25 \%)$ and dimethylpropylamine (12\%). [c] Amide (5 mmol), 4\%Pt-4\%Re/TiO 2 (1.6 mol in metal \%), hexane $(15 \mathrm{ml}), \mathrm{H}_{2}$ (20 bar), $120^{\circ} \mathrm{C}$, Hastelloy ${ }^{\mathrm{TM}}$ autoclave.

Despite this catalyst not being suitable for the hydrogenation of amide substrates containing arene functionalities, it is very effective in catalysing the hydrogenation of aliphatic amides such as $\mathrm{N}$-methylpyrrolidin-2-one and $\mathrm{N}$-methylpropanamide. This catalytic system can be viewed as complementary to our previously reported homogeneous system where aliphatic substrates such as $\mathrm{N}$-methylpyrrolidin-2-one and $\mathrm{N}$ methylpropanamide performed rather poorly, giving either no conversion (Entry 2, Table 1) or poor selectivity (Entry 3, Table 1). ${ }^{\text {[a] }}$ Conversely, hydrogenation of $\mathrm{N}$-methylpyrrolidone or $\mathrm{N}$ methylpropanamide in batch mode with $4 \% \mathrm{Re}-4 \% \mathrm{Pt} / \mathrm{TiO} 2$ under 20 bar of $\mathrm{H}_{2}$ at $120^{\circ} \mathrm{C}$, gave $92-100 \%$ conversion with $75-100 \%$ selectivity towards the desired amines (Entries 5-6, Table 1).

Using the flow reactor described in Figure 1 and $4 \% \mathrm{Pt}$ $4 \% \mathrm{Re} / \mathrm{TiO}_{2}$ as catalyst, $\mathrm{N}$-methylpyrrolidin-2-one could be hydrogenated smoothly under continuous flow to produce $\mathrm{N}$ methylpyrrolidine as the only product. When a solution of $\mathrm{N}$ methylpyrrolidin-2-one in hexane $(0.33 \mathrm{M}$, solution flow rate: 0.06 $\mathrm{ml} / \mathrm{min}$ ) was passed over a fixed catalyst bed of $4 \% \mathrm{Re}-$ $4 \% \mathrm{Pt} / \mathrm{TiO}_{2}$ at $120{ }^{\circ} \mathrm{C}$, together with hydrogen (flow rate: 190 $\mathrm{ml} / \mathrm{min}$ ) under a total pressure of 20 bar, full conversion with $100 \%$ selectivity towards $N$-methylpyrrolidine was achieved over 8 hours on stream (Figure $2 \triangleleft$ ). Pumping $N$-methylpyrrolidin-2one either neat (Figure 2 a) or as an emulsion in supercritical $\mathrm{CO}_{2}$ (total pressure in this case increased to 100 bar, Figure 2 $\triangle)$ led to no catalytic activity. In the first instance presumably due to the polarity of the neat $\mathrm{N}$-methylpyrrolidin-2-one and in the second instance due to the low solubility of the substrate in supercritical $\mathrm{CO}_{2}$. When the original $\mathrm{N}$-methylpyrrolidin-2-one solution in hexane $(0.33 \mathrm{M})$ was again passed over the same catalyst bed (Figure $2 \times$ ), a decrease in the activity was observed, suggesting that the use of supercritical $\mathrm{CO}_{2}$ or neat substrate leads to some catalyst deactivation over time. This is due to strong adsorption of the amide on the surface, which has also been demonstrated in batch experiments by pre-treating the catalyst with $\mathrm{N}$-methylpyrrolidin-2-one in hexane for 3 hours prior to addition of $\mathrm{H}_{2}{ }^{[10]}$

The temperature-programmed oxidation (TPO) profile (Figure 3a) of used $4 \% \mathrm{Pt}-4 \% \mathrm{Re} / \mathrm{TiO}_{2}$ shows an additional broad peak $\left(300-500{ }^{\circ} \mathrm{C}\right)$, compared with that of the fresh catalyst, which is likely to be attributed to adsorbed organic molecules on the surface. The temperature-programmed reduction (TPR) profile of fresh catalyst shows low temperature reduction of $\mathrm{ReO}_{x}$ $\left(\sim 260{ }^{\circ} \mathrm{C}\right)$, which is due to the strong electronic perturbation of the $\mathrm{Re}$ by $\mathrm{Pt}$.

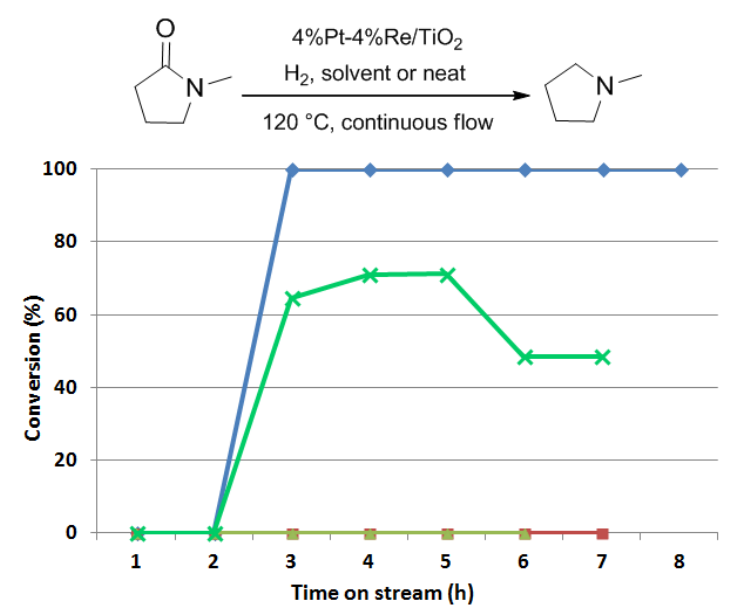

Figure 2. Hydrogenation of $\mathrm{N}$-methylpyrrolidin-2-one with $4 \% \mathrm{Re}-4 \% \mathrm{Pt} / \mathrm{TiO}_{2}$ as catalyst under continuous flow with hexane $(\bullet)$, neat $(\square), \mathrm{scCO}_{2}(\Delta)$ and hexane again $(X)$. 
On the contrary, the TPR profile of used catalyst indicates decreased interaction between $\mathrm{Pt}$ and $\mathrm{Re}$, giving rise to an additional higher temperature reduction peak for $\mathrm{ReO}_{\mathrm{x}}\left(470^{\circ} \mathrm{C}\right)$.
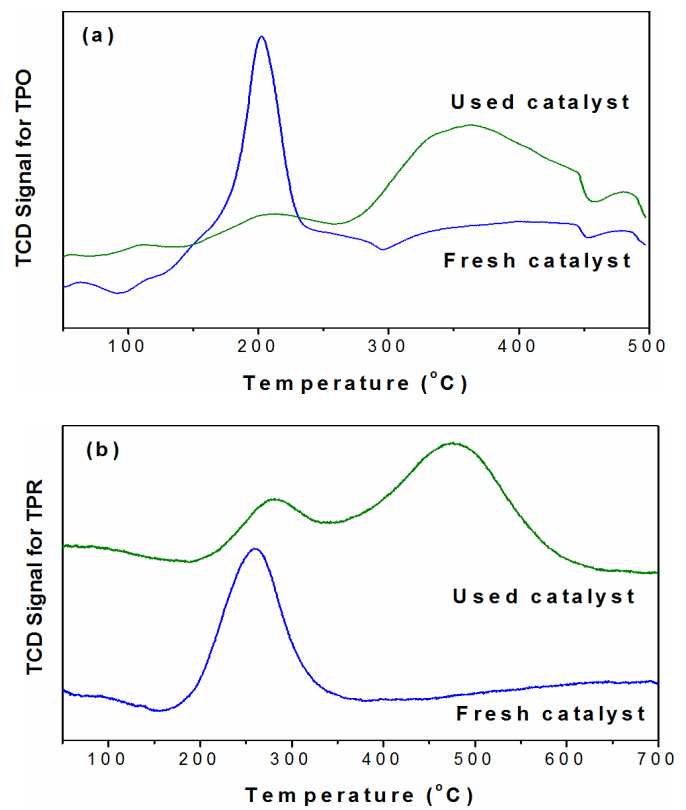

Figure 3. Temperature-programmed (a) oxidation and (b) reduction profiles for Fresh and used $4 \% \mathrm{Pt}-4 \% \mathrm{Re} / \mathrm{TiO}_{2}$ as catalyst.

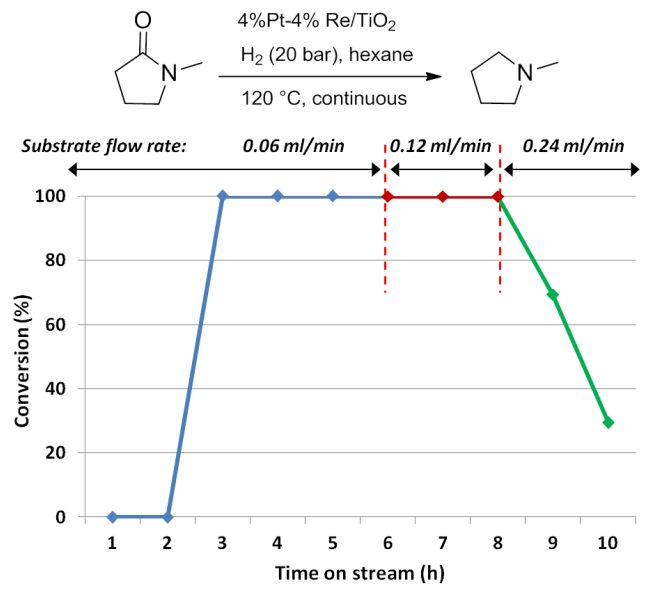

Figure 4. Hydrogenation of $\mathrm{N}$-methylpyrrolidin-2-one with $4 \% \mathrm{Pt}-4 \% \mathrm{Re} / \mathrm{TiO}_{2}$ as catalyst under continuous flow with variation of the substrate flow rate.

For a $0.67 \mathrm{M}$ solution of $\mathrm{N}$-methylpyrrolidin-2-one in hexane under a $\mathrm{H}_{2}$ flow of $190 \mathrm{ml} / \mathrm{min}$, a temperature of $120^{\circ} \mathrm{C}$ and a total pressure of 20 bar, the substrate solution flow rate could be increased to $0.12 \mathrm{ml} / \mathrm{min}$ without any drop in either conversion or selectivity. When the substrate solution flow rate was again doubled $(0.24 \mathrm{ml} / \mathrm{min})$ to give even shorter residence times, a sharp drop in the conversion was observed (Figure 4).

Using the same slightly deactivated catalyst bed used during earlier continuous flow experiments with supercritical $\mathrm{CO}_{2}, \mathrm{~N}$ methylpropanamide could also be hydrogenated successfully under continuous flow. Owing to the low solubility of $\mathrm{N}$ methylpropanamide in hexane, the substrate was passed over the catalyst bed at $120^{\circ} \mathrm{C}$ as an emulsion $(0.94 \mathrm{ml}$ substrate in $85 \mathrm{ml}$ hexane; substrate emulsion flow rate: $0.12 \mathrm{ml} / \mathrm{min}$ ) together with $\mathrm{H}_{2}$ (flow rate $190 \mathrm{ml} / \mathrm{min}$ ) under a total pressure of
20 bar. Under these conditions, high conversion (75-99\%) and selectivity towards the secondary amine (80-86 \%) was achieved continuously over 8 hours on stream (Figure 5), with 1-propanol as the major side-product. Note that since the $\mathrm{N}$ methylpropanamide was fed as an emulsion in hexane, there were some difficulties in maintaining a constant and homogeneous substrate feed despite vigorous stirring. Owing to this complication, the conversion for this reaction varies slightly over time on stream.

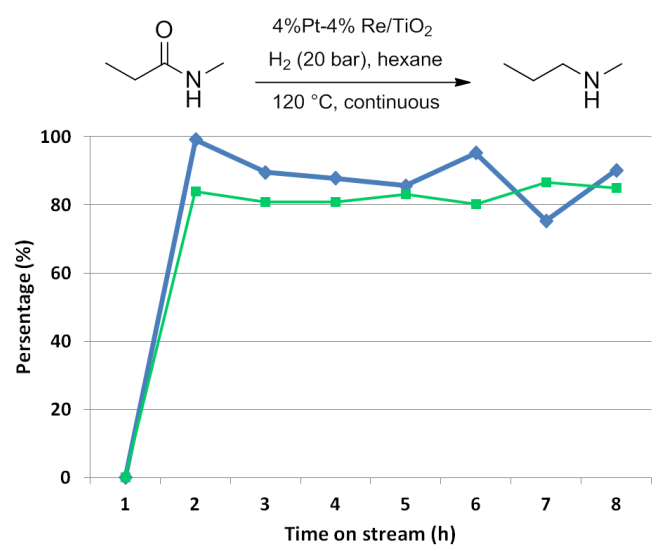

Figure 5. The conversion $(\diamond)$ and selectivity $(\square)$ for the catalytic hydrogenation of $\mathrm{N}$-methylpropanamide with $4 \% \mathrm{Re}-4 \% \mathrm{Pt} / \mathrm{TiO}_{2}$ under continuous flow over an $8 \mathrm{~h}$ period on stream using a recycled catalyst bed.

The low boiling point of hexane resulted in poor mass recovery for continuous flow reactions with this solvent. Thus, decane was employed as a less volatile and more environmentally benign alternative. With decane as solvent, mass recovery of greater than $90 \%$ could be maintained for the hydrogenation of $\mathrm{N}$ methylpyrrolidin-2-one under flow over a $10 \mathrm{~h}$ period on stream [Figure $6(\Delta)$ ]. To evaluate catalyst stability over time, the catalytic hydrogenation of $\mathrm{N}$-methylpyrrolidin-2-one in decane was performed under low conversion with a shorter residence time (substrate solution flow rate: $0.24 \mathrm{ml} / \mathrm{min}, \mathrm{H}_{2}$ flow 190 $\mathrm{ml} / \mathrm{min}$ ). Under these conditions, gradual catalyst deactivation was observed with time on stream, with the greatest deactivation (observed as a sharp drop in conversion) ouccuring within the first four hours on stream [Figure $6(\diamond)$ ].

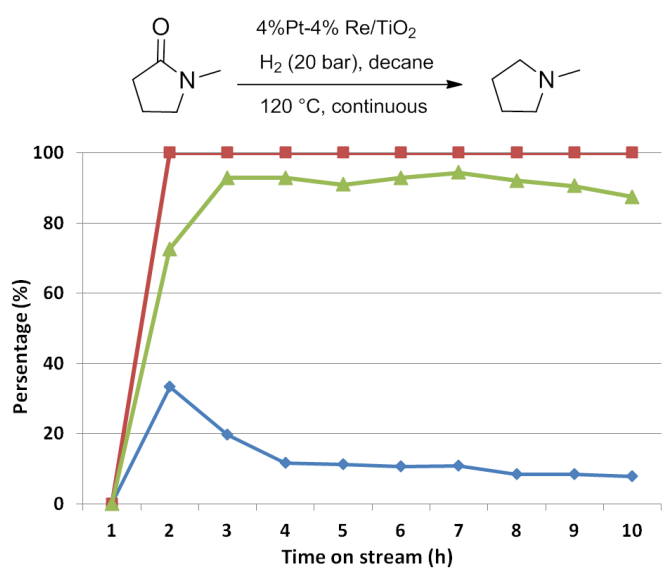

Figure 6. The stability of the $4 \% \mathrm{Re}-4 \% \mathrm{Pt} / \mathrm{TiO}_{2}$ catalyst during the hydrogenation of $\mathrm{N}$-methylpyrrolidin-2-one over a $10 \mathrm{~h}$ period on stream showing the conversion $(\diamond)$, mass recovery $(\Delta)$ and selectivity ( $\square$ ). 
A number of samples taken at different time intervals were analysed for metal content using Inductively Coupled Plasma (ICP) mass spectrometry. In all cases the metal leaching was negligible, with the values measured generally below the detection limit (1 ppm, see ESI table S1). Under batch conditions, the recycle of the catalyst also showed significant deactivation. ${ }^{[10]}$ This was attributed to the loss in the Pt-Re interaction as observed in the TPR, probably due to the exposure to air on recycle causing an exotherm on the partially reduced surface. Under flow conditions, the catalyst is maitained under reducing conditions at all times Therefore, the deactivation observed is likely to be caused by the presence of strongly adsorbed material blocking the surface sites, as observed in the TPO.

In conclusion, we have demonstrated the first catalytic hydrogenation of amides to amines under continuous flow conditions. Aliphatic amides such as $\mathrm{N}$-methylpyrrolidin-2-one and $\mathrm{N}$-metylpropanamide could be hydrogenated successfully under mild conditions in continuous flow using the heterogeneous bimetallic catalyst $4 \% \mathrm{Re}-4 \% \mathrm{Pt} / \mathrm{TiO}_{2}$.

\section{Acknowledgements}

We thank the European Commission for a Fellowship (J. C.). The research leading to these results has received funding from the European Community's Seventh Framework Programme [FP7/20072013] for SYNFLOW under grant agreement $n^{\circ}$ NMP2-LA-2010246461.

\section{Keywords: Amide Hydrogenation • Continuous Flow •} Heterogeneous $\cdot$ Bimetallic $\cdot$ Catalysis

[1] D. J. C. Constable, P. J. Dunn, J. D. Hayler, G. R. Humphrey, J. L. Leazer, Jr., R. J. Linderman, K. Lorenz, J. Manley, B. A. Pearlman, A. Wells, A. Zaks, T. Y. Zhang, Green Chem. 2007, 9, 411-420.

[2] a) S. Hanada, E. Tsutsumi, Y. Motoyama, H. Nagashima, J. Am. Chem. Soc 2009, 131, 15032-15040; b) S. Das, S. Zhou, D. Addis, S. Enthaler, K. Junge, M. Beller, Top Catal. 2010, 53, 979-984; c) S. Das, B. Join, K. Junge, M. Beller, Chem. Commun. 2012, 48, 2683-2685; d) S. Das, B. Wendt, K. Möller, K. Junge, M. Beller, Angew. Chem. Int. Ed. 2012, 51, 1662-1666.

[3] T. Miura, I. E. Held, S. Oishi, M. Naruto, S. Saito, Tetahedron Lett. 2013, 54, 2674-2678.

[4] E. Balaraman, B. Gnanaprakasam, L. J. W. Shimon, D. Milstein, J. Am. Chem. Soc 2010, 132, 16756-16758.

[5] J. M. John, S. H. Bergens, Angew. Chem. Int. Ed. 2011, 50, 1037710380 .

[6] a) J. Coetzee, D. L. Dodds, J. Klankermayer, S. Brosinski, W. Leitner, A. M. Z. Slawin, D. J. Cole-Hamilton, Chem. - Eur. J. 2013, DOI: 10.1002/chem.201204270; b) A. A. Núñez Magro, G. R. Eastham, D. J. Cole-Hamilton, Chem. Commun. 2007, 3154-3156; c) D. L. Dodds, J. Coetzee, J. Klankermayer, S. Brosinski, W. Leitner, D. J. Cole-Hamilton, Chem. Commun. 2012, 48, 12249-12262 (published additions \& corrections).

[7] C. Hirosawa, N. Wakasa, T. Fuchikami, Tetahedron Lett. 1996, 37, 6749-6752.

[8] a) G. Beamson, A. J. Papworth, C. Philipps, A. M. Smith, R. Whyman, J. Catal. 2010, 269, 93-102; b) G. Beamson, A. J. Papworth, C. Philipps, A. M. Smith, R. Whyman, J. Catal. 2011, 278, 228-238.

[9] M. Stein, B. Breit, Angew. Chem. Int. Ed. 2012, 52, 2231-2234.

[10] R. Burch, C. Paun, X. M. Cao, P. Crawford, P. Goodrich, C. Hardacre, P. Hu, L. McLaughlin, J. Sá, J. M. Thompson, J. Catal. 2011, 283, 8997.
Received: ((will be filled in by the editorial staff)) Published online: ((will be filled in by the editorial staff) 


\section{Entry for the Table of Contents}

\section{COMMUNICATION}

Conversion of amides to amines is a key step in pharmaceutical synthesis. It is usually done using stoichiometric amounts of metal hydrides which generate large amounts of waste. Catalytic hydrogenation represents an environmentally benign alternative for this conversion, while flow catalysis allows for ready catalyst separation and high throughput. Here we combine amide hydrogenation and flow catalysis for the first time.

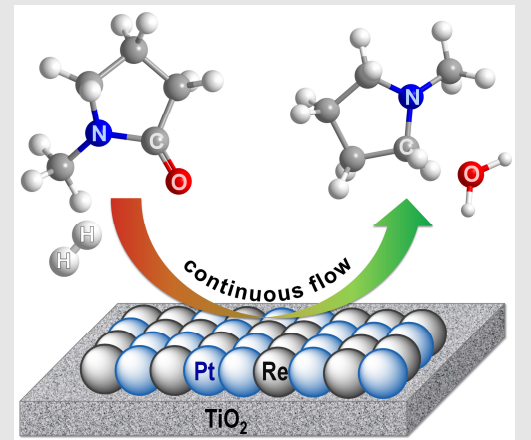

Jacorien Coetzee, Haresh G. Manyar, Christopher Hardacre, David J. ColeHamilton*

Page No. - Page No.

The First Continuous Flow

Hydrogenation of Amides to Amines 


\section{Supporting Information}

for

\section{The First Continuous flow Hydrogenation of Amides to Amines}

Jacorien Coetzee,${ }^{[a]}$ Haresh G. Manyar,${ }^{[b]}$ Christopher Hardacre, ${ }^{[b]}$ and David J. Cole-Hamilton ${ }^{*[a]}$

${ }^{\text {[a] }}$ Dr. J. Coetzee and Prof. D. J. Cole-Hamilton, EaStCHEM, School of Chemistry, North Haugh, University of St. Andrews, St. Andrews, Fife, KY16 9ST, Scotland, United Kingdom.

${ }^{[b]}$ Dr. H. G. Manyar and Prof. C. Hardacre, CenTACat, School of Chemistry and Chemical Engineering, Queen's University Stranmillis Road, Belfast, BT9 5AG, Northern Ireland (United Kingdom).

E-mail: djc@st-andrews.ac.uk

- CONTENTS

SECTION S-1: Experimental. S-2

SECTION S-2: Inductively Coupled Plasma (ICP) mass spectrometry data S-4

SECTION S-3: References. S-5 
SECTION S-1: EXPERIMENTAL

\section{General materials and methods}

Substrate solutions and solvents were handled under an inert atmosphere of $\mathrm{N}_{2}\left[\mathrm{~N}_{2}\right.$, passed through a column of $\mathrm{Cr}$ (II) adsorbed on silica] unless otherwise stated, using standard Schlenk and vacuum-line techniques. [Ru(acac) $)_{3}$, 1,1,1-tris(diphenylphosphinomethyl)ethane (triphos), methanesulfonic acid (MSA) and $\mathrm{N}$-methylpropanamide were all purchased from Aldrich and used without any further purification. Anhydrous $\mathrm{N}$-methylpyrrolidin-2-one was purchased from Alfa Aesar and used as received. Acetanilide was purchased from Aldrich and purified by recrystallisation from toluene prior to use. Tetrahydrofuran and hexane were purchase from Fischer Scientific and dried and degassed using a Braun Solvent Purification System. Decane was purchase from Aldrich and dried by heating over molten sodium $\left(120^{\circ} \mathrm{C}\right)$ for 3-4 hours under an atmosphere of $\mathrm{N}_{2}$ and further degassed by bubbling $\mathrm{N}_{2}$ for $30-40 \mathrm{~min}$. The $4 \% \mathrm{Pt}-4 \% \mathrm{Re} / \mathrm{TiO}_{2}$ catalyst was prepared and characterised using the previously described procedure. ${ }^{[1]}$ All gases were supplied by BOC. Batch reactions using the homogeneous $\left[\mathrm{Ru}(\mathrm{acac})_{3}\right]$ /triphos in situ system were performed using our previously described method. $^{[2]}$

NMR spectra were recorded on a Bruker Avance $300 \mathrm{FT}$, Bruker Avance II $400 \mathrm{MHz}$ or Bruker Avance III $500 \mathrm{MHz}$ spectrometer ( ${ }^{1} \mathrm{H}$ NMR at $300 / 400 / 500 \mathrm{MHz}$ ) with chemical shifts reported relative to tetramethylsilane (TMS). ${ }^{1} \mathrm{H}$ NMR spectra were referenced internally to deuterated solvent resonances which were referenced relative to TMS. Conversions and selectivities were calculated using the measured ${ }^{1} \mathrm{H}$ NMR integrals. GC-MS chromatograms were recorded on a Hewlett Packard 6890 series GC system equipped with an Agilent J\&W HP-1 general purpose column (fused silica capillary) and an HP 5973 Mass selective detector for both qualitative (MS) and quantitative (FID) analysis. A Hewlett-Packard Chemstation allowed for the computerised integration of peak areas. Method: flow rate $1 \mathrm{ml} \mathrm{min}^{-1}$ (He carrier gas), split ratio $100: 1$, starting temperature $50{ }^{\circ} \mathrm{C}(4 \mathrm{~min})$ ramp rate $20{ }^{\circ} \mathrm{C} \min ^{-1}$ to $130{ }^{\circ} \mathrm{C}(2 \mathrm{~min})$, ramp rate $20{ }^{\circ} \mathrm{C} \mathrm{min}^{-1}$ to $220{ }^{\circ} \mathrm{C}(15.5 \mathrm{~min})$. Selected samples collected during catalytic reactions under continuous flow were analysed for metal content using Inductively Coupled Plasma (ICP) mass spectrometry performed using a Perkin-Elmer Optima 4300 ICP-OES system.

\section{Reactor equipment specifications}

A custom designed reactor was used for all catalytic reactions under continuous flow conditions (Figure $\mathrm{S} 1$ ). The $\mathrm{H}_{2}$ used in the reactions was fed into the system from a ballast vessel pressurised using a Haskel AG75 gas booster. The hydrogen flow rate was controlled by a BROOKS 0154 mass flow controller (MFC), while the total pressure in the reactor was controlled by a Jasco BP-1580-81 back pressure regulator. Non return valves were fitted after the $\mathrm{H}_{2}$ line to avoid $\mathrm{CO}_{2}$ or any liquids from entering the MFC. The substrate feed was maintained at the desired flow rate by a Gilson 305 HPLC pump and mixed with the gases before entering the reactor. The liquid and gas mixture was first preheated in a coil wrapped around a heated aluminium block at $100^{\circ} \mathrm{C}$ prior to passing over the catalyst bed. A filter was fitted after the catalyst bed to avoid any solids from entering the decompression system. In the case where supercritical $\mathrm{CO}_{2}$ was used, the $\mathrm{CO}_{2}$ was introduced into the reactor via a chilled Jasco PU-1580- $\mathrm{CO}_{2}$ delivery pump. Swagelok fittings and valves together with transfer lines of the appropriate pressure rating were used for the rest of the setup with the pressure monitored in various parts of the reactor by pressure transducers (P1-P3; Figure S1). In addition, an emergency pressure relief valve was fitted before the preheating coil to as an additional safety measure. 


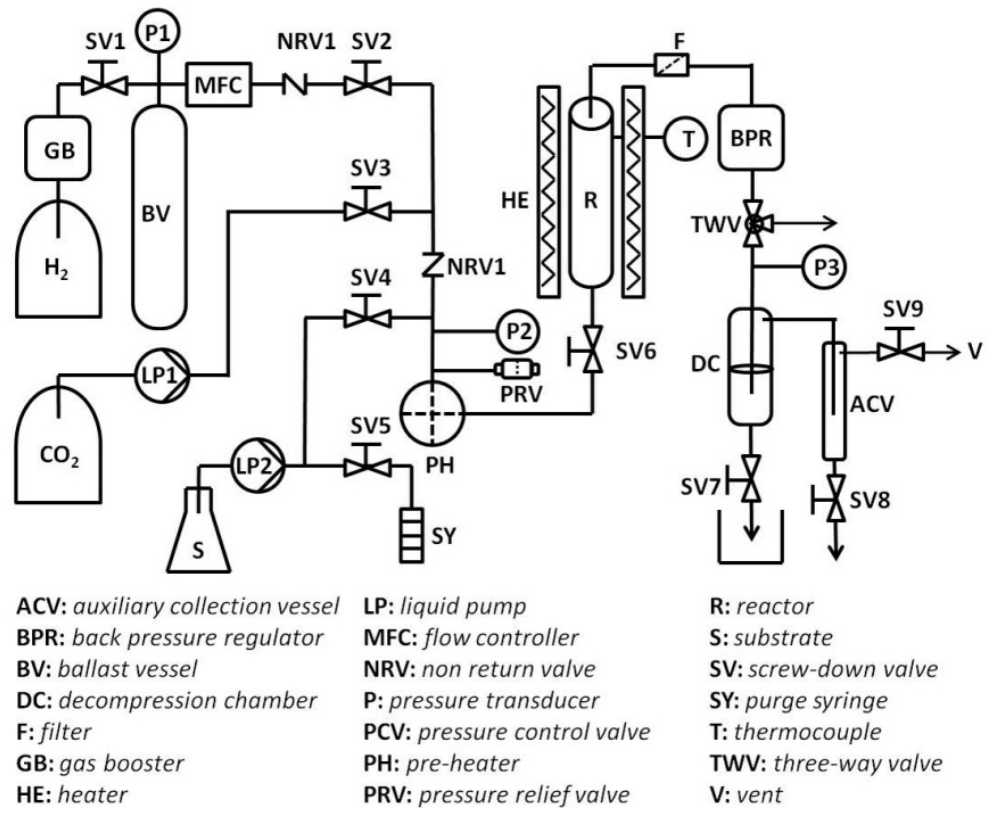

Figure S1. Schematic drawing of the continuous flow reactor.

\section{General procedure for catalytic batch reactions with $4 \% \mathrm{Re}-4 \% \mathrm{Pt} / \mathrm{TiO}_{2}$}

Batch reactions with $4 \% \mathrm{Pt}-4 \% \mathrm{Re} / \mathrm{TiO}_{2}$ were performed using either the earlier described literature procedure ${ }^{[1]}$ or using the slightly varied method described here. $4 \% \mathrm{Pt}-4 \% \mathrm{Re} / \mathrm{TiO}_{2}(0.10 \mathrm{~g}, 0.04 \mathrm{mmol}$ in metal) was added to a Hastelloy ${ }^{\mathrm{TM}}$ autoclave fitted with a stirrer bar in air. The autoclave was then sealed and purged by three vacuum $/ \mathrm{N}_{2}$ cycles using a Schlenk line. A septum was fitted and the relevant amide substrate $(5 \mathrm{mmol})$ together with dry, degassed hexane $(15 \mathrm{ml})$ was introduced via syringe under a flow of $\mathrm{N}_{2}$ (Note: In the case of acetanilide, the solid substrate was added to the autoclave together with the catalyst in the first step). The autoclave was sealed again, purged ( 10 bar $\mathrm{H}_{2}, 4$ times), pressure tested (40-50 bar of $\mathrm{H}_{2}$ ) and pressurised with $\mathrm{H}_{2}(20$ bar). The autoclave was heated with stirring to an internal temperature of $120^{\circ} \mathrm{C}$ using an external heating jacket for $16 \mathrm{~h}$. At the end of the reaction, the autoclave was cooled rapidly by immersing the autoclave in cold water. After venting the autoclave to the atmosphere in a well-ventilated fumehood, the contents was transferred to a sample vial in air and analysed using GC-MS, GC-FID and NMR spectroscopy. Quantitative calculations were based on recorded ${ }^{1} \mathrm{H}$ NMR spectra.

\section{General procedure for catalytic hydrogenations with $4 \% \mathrm{Re}-4 \% \mathrm{Pt} / \mathrm{TiO}_{2}$ under continuous flow conditions}

$4 \% \mathrm{Pt}-4 \% \mathrm{Re} / \mathrm{TiO}_{2}(1.0 \mathrm{~g}, 0.42 \mathrm{mmol}$ in metal) was introduced into a tubular reactor fitted with a plug of glass wool on either side in air (Figure S2). The reactor was then assembled, purged with $\mathrm{H}_{2}$ and checked for leaks under a pressure of $\mathrm{H}_{2}$ (50 bar). Prior to commencing the substrate feed, the catalyst was first prereduced by heating the catalyst bed for $1 \mathrm{~h}$ at $120^{\circ} \mathrm{C}$ under a flow of $\mathrm{H}_{2}(100$ $\mathrm{ml} / \mathrm{min}$; total pressure $20 \mathrm{bar}$. During this time the preheater was set to $100^{\circ} \mathrm{C}$ and the temperature allowed to stabilise. Similarly, where $\mathrm{CO}_{2}$ was used, the $\mathrm{CO}_{2}$ delivery pump was also turned on at this stage and allowed to stabilise. The liquid pump was purged with $\mathrm{N}_{2}$ and primed with substrate. If $\mathrm{CO}_{2}$ was used, the $\mathrm{CO}_{2}$ flow was started at this point. Lastly, the $\mathrm{H}_{2}$ flow rate was increased to $190 \mathrm{ml} / \mathrm{min}$ and when all the flows and temperatures were stable, the substrate solution was introduced at the desired flow rate. The product mixtures were collected upon decompression into chilled (using solid 
$\mathrm{CO}_{2}$ ) collection vessels and weighed to calculate the mass balance. Samples were collected hourly and analysed using GC-MS, GC-FID and NMR spectroscopy. Quantitative calculations were based on recorded ${ }^{1} \mathrm{H}$ NMR spectra.

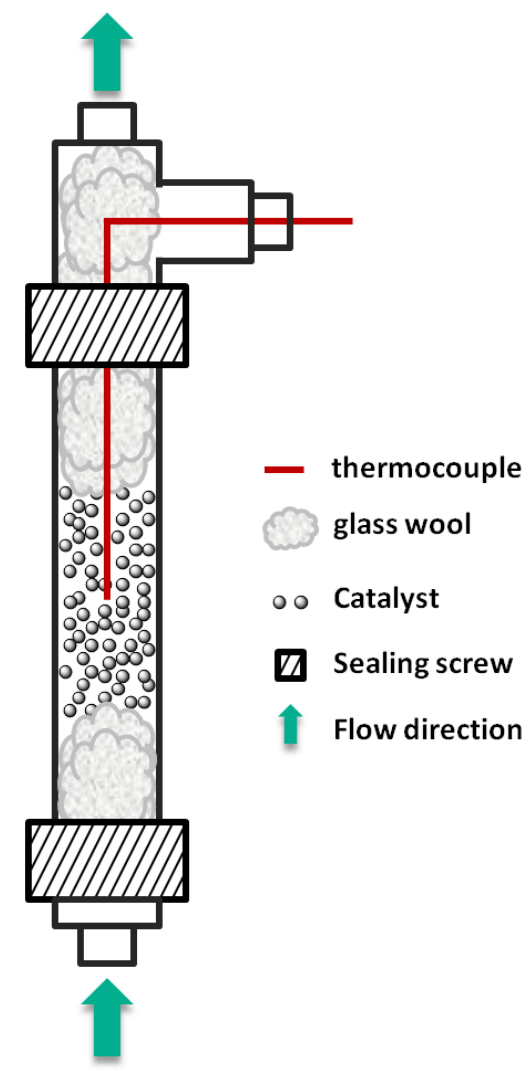

Figure S1. Schematic drawing of the tubular reactor set-up.

SECTION S-2: INDUCTIVELY COUPLED PLASMA (ICP) MASS SPECTROMETRY DATA

The metal content of the final product mixtures collected at selected time intervals for catalytic amide hydrogenations using $4 \% \mathrm{Pt}-4 \% \mathrm{Re} / \mathrm{TiO}_{2}$ under continuous flow conditions was determined by ICP-MS analysis. The analysis was performed using a Perkin-Elmer Optima 4300 ICP-OES. The results are summarised in Table S1.

\begin{tabular}{|ccccc|}
\hline \multicolumn{4}{|c|}{ Table S1. Inductively Coupled Plasma Mass spectrometry data for product samples collected for catalytic } \\
amide hydrogenations with 4\%Pt-4\%Re/TiO
\end{tabular}

${ }^{a}$ Conditions: $4 \% R e-4 \% \mathrm{Pt}_{\mathrm{TiO}}\left(1.0 \mathrm{~g}, 0.42 \mathrm{mmol}\right.$ in metal), $120{ }^{\circ} \mathrm{C}, \mathrm{H}_{2}$ flow rate $-190 \mathrm{ml} / \mathrm{min}$, total pressure -20 bar.

${ }^{b}$ Substrate introduced as a $0.33 \mathrm{M}$ solution in decane (flow rate: $0.24 \mathrm{ml} / \mathrm{min}$ ). 
[1] R. Burch, C. Paun, X. M. Cao, P. Crawford, P. Goodrich, C. Hardacre, P. Hu, L. McLaughlin, J. Sá, J. M. Thompson, J. Catal. 2011, 283, 89-97.

[2] J. Coetzee, D. L. Dodds, J. Klankermayer, S. Brosinski, W. Leitner, A. M. Z. Slawin, D. J. ColeHamilton, Chem. - Eur. J. 2013, DOI: 10.1002/chem.201204270. 